\title{
Reproductive performance of freshwater prawn Macrobrachium rosenbergii (De Man 1879) broodstocks grown on different diets
}

\author{
A. F. M. Shofiquzzoha*, S. M. Haque and M. A. Wahab \\ Department of Fisheries Management, Bangladesh Agricultural University, Mymensingh-2202, Bangladesh *E-mail: \\ zohabfri@yahoo.com
}

\begin{abstract}
An experiment was carried out during April to September 2013 to compare the reproductive performance of freshwater prawn golda (Macrobrachium rosenbergii) broodstocks fed on diets including 3 commercial (Mega $-\mathrm{F}_{1}$, SABINCO- $\mathrm{F}_{2}$ and $\left.C P-\mathrm{F}_{3}\right)$ and a laboratory formulated test feed $\left(\mathrm{F}_{4}\right)$. Post larvae $(\mathrm{PL})$ were collected from the river Kocha of district Pirozpur in April 2012 and nursed in the hapa (net cage) then reared in earthen ponds at the Fisheries Field Laboratory, Bangladesh Agricultural University (BAU), Mymensingh. The broods were fed with selective feeds since their PL stage. The feeding was continued till their maturity of both male and female up to berried females. The proximate composition of the feeds, $F_{1}$ where crude protein, 33.49\%, lipid 5.38\%, carbohydrate $30.31 \%, F_{2}$-crude protein, $26.70 \%$, lipid $5.50 \%$, carbohydrate $34.34 \%$, $\mathrm{F}_{3^{-}}$crude protein, 38.90\%, lipid $8.09 \%$, carbohydrate $25.37 \%$ and treatment $\mathrm{F}_{4^{-}}$crude protein $33.00 \%$, lipid $11.13 \%$, carbohydrate $25.43 \%$. Feeds were supplied at 5\% body weight twice at dawn (5:30-6:00 am) and dusk (5:30-7:30 pm) till the end of the experiment. The variation in most water quality parameters, temperature, alkalinity, $\mathrm{DO}$, transparency, TDS, conductivity $\mathrm{NO}_{2}^{-}-\mathrm{N}^{-} \mathrm{PO}_{4}^{-}$ ${ }^{3}$ and chlorophyll-a were insignificant; while parameters, water depth, $\mathrm{pH}, \mathrm{NH}_{3}-\mathrm{N}$ and $\mathrm{NO}_{3}{ }^{-}-\mathrm{N}$ was found to vary significantly $(p<0.05)$ among treatments. Brood observation was carried out by dragging seine net or/and hand picking for eggs in egg chamber remained intact. The male and female ratio estimated 1:2.8, 1: 2.4, 1: 2.4 and 1: 1.7 in the treatments $F_{1}, F_{2}, F_{3}$ and $F_{4}$. The weight of the berried females was $56.33 \pm 19.55 \mathrm{~g}, 85.50 \pm 14.85 \mathrm{~g}$, $73.67 \pm 23.09 \mathrm{~g}$ and $94.50 \pm 51.62 \mathrm{~g}$; total weight of eggs was $7.61 \pm 1.86 \mathrm{~g}, 7.04 \pm 0.69 \mathrm{~g}, 10.26 \pm 1.41 \mathrm{~g}$ and $6.15 \pm 1.20 \mathrm{~g}$ in $F_{1}, F_{2}, F_{3}$ and $F_{4}$. The estimated numbers of eggs were $53,889 \pm 10,541,37,555 \pm 1,217,59,640 \pm 5,270$ and $36,017 \pm 7,790$ in $F_{1}, F_{2}, F_{3}$ and $F_{4}$ respectively. The weight of berried females with eggs (g), total eggs (g) and estimated number of eggs were significant $(p<0.05)$ among treatments. Females fed with commercial feed $F_{3}(C P)$ were found to produce the sufficient number of eggs $\left(59,640 /\right.$ female) followed by $F_{1}$ (Mega). The findings may contribute to the better broodstock management of freshwater prawn to produce of a sufficient number of embryonic eggs for hatchery operation.
\end{abstract}

Keywords: Freshwater prawn, Broodstocks, Reproductive performance, Different diets

\section{Introduction}

Freshwater prawn (Macrobrachium rosenbergii, De Man 1879) locally known golda is one of the important aquaculture species in Bangladesh. About 75,000 ha land is being used for golda culture and it produce about 41,000 Mt in 2012 (DoF 2013). Due to its increasing demand and as a priority sector for economic growth, Bangladesh has its rapid extension of cultural practices. On the question of culture, seed availability is the prime consideration. Since culture practices began in the country, the seed of freshwater prawn i.e., post larvae (PL) were largely collected from wild sources (Ahmed 2008). Due to the rapid extension of cultural practices, in many parts of the world, a huge number of PL were collected from nature (Mohanta 2000) and concerning the biodiversity conservation, however, exerted ban in many countries including Bangladesh. About 80 golda hatcheries (DoF 2012) have been established for the last couple decades in the country among which 70 are existing (DoF 2013) and each of them requires about 520 berried females in a productive year (Sardar et al. 2013). The majority of the hatcheries are to fulfill their brood requirement from wild sources, while a few are from cultural farms and the number is inadequate. The availability of qualitative berried females is essential for the successful hatchery operation and production of PL. However, development of a large scale brood in captive conditions with proper nourishment is prerequisite for quality seed production. An attempt was taken to develop a suitable feeding regime using locally available commercial and laboratory prepared feeds for the proper nourishment of quality berried females for hatchery operations. 


\section{Methods and Materials}

The experiment was carried out during April to September 2013 to compare the reproductive performance of freshwater prawn Golda (Macrobrachium rosenbergii) broodstocks fed on four diets including 3 commercial (Mega $-F_{1}$, SABINCO- $F_{2}$ and $\left.C P-F_{3}\right)$ and a laboratory prepared test feed $\left(F_{4}\right)$.

\section{Collection of PL}

Wild post larvae $(P L)$ were collected from the river Kocha of district Pirozpur in late April 2012 within the location $22^{\circ} 35^{\prime} 521^{\prime \prime} \mathrm{N}, 90^{\circ} 0052.38^{\prime \prime}-03^{\prime} 18.52^{\prime \prime} \mathrm{E}$, and $22^{\circ} 29^{\prime} 531^{\prime \prime} \mathrm{N}, 90^{\circ} 00^{\prime} 536^{\prime \prime}-01^{\prime} 461^{\prime \prime} \mathrm{E}$ (position taken by GARMIN-GPSMAP 765).

\section{Nursing of PL and rearing broods}

The collected PL were carried in the oxygenated polyethylene bags and nursed initially at a density 350 $\mathrm{PL} \mathrm{m} \mathrm{m}^{-2}$ in the fine meshed $(0.5 \mathrm{~mm})$ nylon hapa (net cage) of size $1 \mathrm{~m} \times 1 \mathrm{~m} \times 2.5 \mathrm{~m}$ for 30 days in the earthen ponds at the Fisheries Field Laboratory, Bangladesh Agricultural University (BAU), Mymensingh (24ㄴㄱ' $32.70^{\prime \prime} \mathrm{N}$ and $90^{\circ} 25^{\prime} 43.69^{\prime \prime} \mathrm{E}$ - Google Earth). The juveniles were then reared in 12 earthen ponds, each of $40 \mathrm{~m}^{2}$ under 4 treatments and 3 replications each. The juveniles were stocked randomly at a density of $3 \mathrm{~m}^{-2}$.

\section{Feed and Feeding}

The broods were fed with selective locally available 3 commercial (Mega $-F_{1}$, SABINCO- $F_{2}$ and CP- $F_{3}$ ) pelleted feeds and a laboratory formulated test feed $\left(F_{4}\right)$ since their PL stage. The feeding was continued till their maturity of both male and female to obtain the berried females. The proximate composition of the feeds, $F_{1}$ where crude protein, $33.49 \%$, lipid $5.38 \%$, carbohydrate $30.31 \%$; $F_{2}$ - crude protein, $26.70 \%$, lipid $5.50 \%$, carbohydrate $34.34 \%$; $F_{3^{-}}$crude protein, $38.90 \%$, lipid $8.09 \%$, carbohydrate $25.37 \%$ and treatment $\mathrm{F}_{4^{-}}$crude protein $33.00 \%$, lipid $11.13 \%$, carbohydrate $25.43 \%$. Feeds were supplied at $5 \%$ body weight, twice at dawn (5:30-6:00 am) and dusk (5:30-7:30 pm) until the end of the experiment.

\section{Monitoring of water quality parameters}

The water quality parameters, i.e., water temperature, $\mathrm{pH}$, dissolved oxygen (DO), depth, transparency, total dissolved solids (TDS), conductivity, alkalinity, ammonia nitrogen $\left(\mathrm{NH}_{3}-\mathrm{N}\right)$, nitrite nitrogen $\left(\mathrm{NO}_{2}-\mathrm{N}\right)$, nitrate nitrogen $\left(\mathrm{NO}_{3}-\mathrm{N}\right)$, phosphate $\left(\mathrm{PO}_{4}^{-3}\right)$ and chlorophyll-a were monitored fortnightly. The devices, portable Multiparameter: $H A C H$ sension ${ }^{T M} 156$ and $H A C H$ DR 4000 version 2.35 were used in the Water Quality and Pond Dynamics Laboratory, Bangladesh Agricultural University (BAU) for measuring major physical-chemical parameters. Water depth was measured by a meter scale, and total alkalinity was estimated by the titration method using $0.02 \mathrm{~N} \mathrm{H} 2 \mathrm{SO} 4$ and Methyl Orange indicator. The chlorophyll-a was estimated followed by Vollenweider's equation methods (Stirling, 1985) using a spectrophotometer (SPECTRONIC ${ }^{\circledR}$ GENISYS $^{\text {TM }}$ ) at wavelengths 664 and $750 \mathrm{~nm}$.

\section{Examination of berried females}

The broods were examined every week during April to September for observing their gonadal developments followed by a collection of berried females from all treatments. Broods were collected either by dragging a seine net or hand picking carefully so that the embryos in egg chamber were remained intact.

\section{Collection eggs from berried females}

The berried females were immediately transferred to the plastic buckets containing about 3 liters of pond water which aerated with handy portable dry cell operated aerator. The length and weight of the females were recorded. The eggs were carefully examined on the basis of embryonic development of major three color phases, i.e., orange, yellow and brown was recorded. A portion of yellow and brown eggs (approx. $1-2 \mathrm{~g}$ ) from each berried female was collected with the help of forceps and scissors and placed in $5 \mathrm{ml}$ plastic vials containing Bouin's fluid. 


\section{Assessment of eggs}

A small part of collecting eggs were weighted by an electronic balance (METTLER TOLEDO B2002-S) and placed on a watch glass. The egg sample was then washed with distilled water to remove Bouin's fluid and placed in $10 \mathrm{ml}$ of $1 \%$ sodium sulfite $\left(\mathrm{Na}_{2} \mathrm{SO}_{3}\right)$ solution for half an hour to remove the stickiness of eggs (Fisher et al. 1999). The eggs then placed on a glass slide and counted manually under an electric microscope (Olympus $\mathrm{BH} 2$ ). The eggs were measured along their axis length (wide side), and the transverse width (narrow side). The egg size was measured with the help of a kilometer. The number of eggs per mg was counted. Total weight of eggs of a berried female was determined by individual weighing with eggs minus individual without eggs just after hatching.

\section{Analysis of data}

One way ANOVA was done among the treatments followed by Duncan PostHoc analysis for multiple comparisons. Statistical analysis was done with the help of software packages MS Excel version 2010 and SPSS version 16 for Windows.

\section{Results and Discussion}

Water quality parameters measured in the experiment were shown in Table 1. Water temperature, transparency, DO, total alkalinity, TDS, conductivity, $\mathrm{NO}_{2}-\mathrm{N}, \mathrm{PO}_{4}^{-3}$ and chlorophyll-a did not vary among treatments, while depth, $\mathrm{pH}, \mathrm{NH}_{3}-\mathrm{N}$ and $\mathrm{NO}_{3}-\mathrm{N}$ varied significantly $(\mathrm{p}<0.05)$ during the experimental period. The mean values of water parameters of all four treatments were, temperature $30.57 \pm 1.35^{\circ} \mathrm{C}$, depth $99.83 \pm 7.74 \mathrm{~cm}$, transparency $34.45 \pm 9.00 \mathrm{~cm}$, TDS $134.05 \pm 38.26 \mathrm{mg} / \mathrm{L}$, conductivity 276.47 $\pm 77.21 \mu \mathrm{S} / \mathrm{cm}$; while properties like, DO $3.71 \pm 1.11 \mathrm{mg} / \mathrm{L}, \mathrm{pH} 8.55 \pm 0.59$, total alkalinity $139.31 \pm 31.55$ $\mathrm{mg} / \mathrm{L}, \mathrm{NH}_{3}-\mathrm{N} 0.21 \pm 0.10 \mathrm{mg} / \mathrm{L}, \mathrm{NO}_{2}-\mathrm{N} 0.01 \pm 0.01, \mathrm{NO}_{3}-\mathrm{N} 0.02 \pm 0.03$ and $\mathrm{PO}_{4}{ }^{-3} 1.15 \pm 0.94 \mathrm{mg} / \mathrm{L}$ were estimated, while the chlorophyll-a was obtained $11.44 \pm 10.42 \mu \mathrm{g} / \mathrm{L}$ in all the treatments. The parameters were within the optimal ranges for prawn culture and agreed to Mohanta, 2000; Habashy et al., 2012; the range of $\mathrm{pH}$ between 7-8.5 and alkalinity 50- $150 \mathrm{mg} / \mathrm{L}$ was reported by D'Abramo et al. 2006, conductivity was within the range described by Bhatnagar and Devi (2013). In wild populations of $M$. rosenbergii, spawning occurs in temperature between 29 and $30.5^{\circ} \mathrm{C}$ mentioned by Rao (1991) which is a little bit lower than present findings.

The cultural features of the broodstocks developed on different feeds are shown in the Table 2. The survival of prawns in the broodstock was estimated at the end of the experiment and was significant $(p<0.05)$ among treatments. It seems to be lower survival of the broods were directly related to their cultural duration as well on the efficacy of the feed regimes. The highest survival in treatment $\mathrm{F}_{3}$ (46.11\%), followed by $F_{1}(39.72 \%)$ and $F_{2}(37.22 \%)$ while lowest survival in treatment $F_{4}(24.72 \%)$ was estimated. The survival of females $50-60 \%$ and for males $20-30 \%$ of broodstocks was reported by Tidwell et al. (2005). The first berried females were obtained minimum at 295 days and maximum 315 days since the PL stocked in the experiment in different treatments. The male female ration was estimated 1:2.8, 1:2.4, 1:2.4 and 1:1.7 in the treatments $F_{1}, F_{2}, F_{3}$ and $F_{4}$, respectively.

The ultimate aim of the experiment was to assess the performances through numbers of eggs produced by the berried females in broodstocks those were developed under three commercial and one laboratory prepared feed. The results are analyzed and showed in the Table 3. The obtained weight of the berried females with embryonic eggs $56.33 \mathrm{~g}, 85.50 \mathrm{~g}, 73.67 \mathrm{~g}$ and $94.50 \mathrm{~g}$ were significantly varied $(\mathrm{p}<0.05)$ among treatments $F_{1}, F_{2}, F_{3}$ and $F_{4}$ respectively. The total mean weights of embryonic eggs were $7.61 \mathrm{~g}$, $7.04 \mathrm{~g}, 10.26 \mathrm{~g}$ and $6.15 \mathrm{~g}$, in the treatments $F_{1}, F_{2}, F_{3}$ and $F_{4}$ respectively, was also found statistically significant $(p<0.05)$. The embryonic egg sizes of both the axis length (wide side) $0.51,0.62,0.60,0.56$ $\mathrm{mm}$ and the transverse width (narrow side) $0.47,0.57,0.51,0.48 \mathrm{~mm}$ were measured in the treatments $F_{1}, F_{2}, F_{3}$ and $F_{4}$ respectively. The embryonic egg sizes were found significantly varied $(p<0.05)$ both in axis length and transverse width among treatments, however eggs sizes were almost similar to Habashy et al. (2012). The estimated numbers of eggs were 53,889 $\pm 10,541,37,555 \pm 1,217,59,640 \pm 5,270$ and $36,017 \pm 7,790$ in treatments $F_{1}, F_{2}, F_{3}$ and $F_{4}$, respectively. 
Table 1. Water quality parameters of the broodstocks rearing earthen ponds during the experiment period

\begin{tabular}{|c|c|c|c|c|c|c|}
\hline Water Parameters & $\begin{array}{c}F_{1} \\
\text { Mean } \\
\pm S D\end{array}$ & $\begin{array}{l}\mathbf{F}_{2} \\
\text { Mean } \\
\pm S D\end{array}$ & $\begin{array}{l}\mathbf{F}_{3} \\
\text { Mean } \\
\pm S D\end{array}$ & $\begin{array}{l}\mathbf{F}_{4} \\
\text { Mean } \\
\pm S D\end{array}$ & $\begin{array}{l}\text { Total } \\
\text { Mean } \\
\pm S D\end{array}$ & Remarks \\
\hline Water temp. $\left(C^{0}\right)$ & $\begin{array}{l}30.54 \\
\pm 1.55\end{array}$ & $\begin{array}{l}31.11 \\
\pm 0.96\end{array}$ & $\begin{array}{l}30.77 \\
\pm 1.42\end{array}$ & $\begin{array}{c}30.58 \pm \\
1.48\end{array}$ & $\begin{array}{l}30.57 \\
\pm 1.35\end{array}$ & NS \\
\hline Depth (cm) & $\begin{array}{c}97.09^{\mathrm{ab}} \\
\pm 5.78\end{array}$ & $\begin{array}{c}100.09^{\mathrm{ab}} \\
\pm 5.85\end{array}$ & $\begin{array}{c}101.32^{\mathrm{a}} \\
\pm 6.18\end{array}$ & $\begin{array}{l}98.91^{\mathrm{b}} \\
\pm 7.74\end{array}$ & $\begin{array}{l}99.83 \\
\pm 7.74\end{array}$ & * \\
\hline Transparency (cm) & $\begin{array}{c}39.12 \\
\pm 11.23\end{array}$ & $\begin{array}{l}38.73 \\
\pm 9.09\end{array}$ & $\begin{array}{c}36.06 \\
\pm 10.94\end{array}$ & $\begin{array}{l}37.17 \\
\pm 7.70\end{array}$ & $\begin{array}{l}34.45 \\
\pm 9.00\end{array}$ & NS \\
\hline DO (mg/L) & $\begin{array}{c}3.97 \\
\pm 1.05\end{array}$ & $\begin{array}{c}3.70 \\
\pm 1.21\end{array}$ & $\begin{array}{c}3.69 \\
\pm 1.21\end{array}$ & $\begin{array}{c}3.63 \\
\pm 1.02\end{array}$ & $\begin{array}{c}3.71 \\
\pm 1.11\end{array}$ & NS \\
\hline $\mathrm{pH}$ & $\begin{array}{l}8.73^{\mathrm{a}} \\
\pm 0.67\end{array}$ & $\begin{array}{l}8.60^{a b} \\
\pm 0.71\end{array}$ & $\begin{array}{l}8.57^{\mathrm{ab}} \\
\pm 0.73\end{array}$ & $\begin{array}{l}8.28^{\mathrm{a}} \\
\pm 0.60\end{array}$ & $\begin{array}{c}8.55 \\
\pm 0.59\end{array}$ & * \\
\hline Alkalinity (mg/L) & $\begin{array}{l}139.62 \\
\pm 34.97\end{array}$ & $\begin{array}{l}142.35 \\
\pm 30.75\end{array}$ & $\begin{array}{l}136.82 \\
\pm 29.63\end{array}$ & $\begin{array}{l}139.24 \\
\pm 31.79\end{array}$ & $\begin{array}{l}139.51 \\
\pm 31.55\end{array}$ & NS \\
\hline TDS (mg/L) & $\begin{array}{l}132.84 \\
\pm 38.68\end{array}$ & $\begin{array}{l}141.93 \\
\pm 39.22\end{array}$ & $\begin{array}{l}130.75 \\
\pm 35.23\end{array}$ & $\begin{array}{l}130.68 \\
\pm 40.32\end{array}$ & $\begin{array}{l}134.05 \\
\pm 38.26\end{array}$ & NS \\
\hline Conductivity $(\mu \mathrm{S} / \mathrm{cm})$ & $\begin{array}{l}276.60 \\
\pm 79.47\end{array}$ & $\begin{array}{l}289.26 \\
\pm 75.45\end{array}$ & $\begin{array}{l}272.26 \\
\pm 72.66\end{array}$ & $\begin{array}{l}267.76 \\
\pm 82.67\end{array}$ & $\begin{array}{l}276.47 \\
\pm 77.21\end{array}$ & NS \\
\hline $\mathrm{NH}_{3}-\mathrm{N}(\mathrm{mg} / \mathrm{L})$ & $\begin{array}{l}0.17^{\mathrm{b}} \\
\pm 0.07\end{array}$ & $\begin{array}{l}0.19^{\mathrm{ab}} \\
\pm 0.08\end{array}$ & $\begin{array}{l}0.23^{\mathrm{a}} \\
\pm 0.13\end{array}$ & $\begin{array}{l}0.23^{\mathrm{a}} \\
\pm 0.10\end{array}$ & $\begin{array}{c}0.21 \\
\pm 0.10\end{array}$ & * \\
\hline $\mathrm{NO}_{2}-\mathrm{N}(\mathrm{mg} / \mathrm{L})$ & $\begin{array}{c}0.01 \\
\pm 0.01\end{array}$ & $\begin{array}{c}0.01 \\
\pm 0.00\end{array}$ & $\begin{array}{c}0.01 \\
\pm 0.01\end{array}$ & $\begin{array}{c}0.01 \\
\pm 0.02\end{array}$ & $\begin{array}{c}0.01 \\
\pm 0.01\end{array}$ & NS \\
\hline $\mathrm{NO}_{3}-\mathrm{N}(\mathrm{mg} / \mathrm{L})$ & $\begin{array}{l}0.01^{b} \\
\pm 0.03\end{array}$ & $\begin{array}{l}0.03^{\mathrm{ab}} \\
\pm 0.03\end{array}$ & $\begin{array}{l}0.03^{\mathrm{a}} \\
\pm 0.03\end{array}$ & $\begin{array}{l}0.02^{\mathrm{ab}} \\
\pm 0.03\end{array}$ & $\begin{array}{c}0.02 \\
\pm 0.03\end{array}$ & * \\
\hline $\mathrm{PO}_{4}^{-3}(\mathrm{mg} / \mathrm{L})$ & $\begin{array}{c}1.04 \\
\pm 0.92\end{array}$ & $\begin{array}{c}1.15 \\
\pm 0.96\end{array}$ & $\begin{array}{c}1.21 \\
\pm 0.97\end{array}$ & $\begin{array}{c}1.20 \\
\pm 0.93\end{array}$ & $\begin{array}{c}1.15 \\
\pm 0.94\end{array}$ & NS \\
\hline Chlorophyll-a ( $\mu \mathrm{g} / \mathrm{L})$ & $\begin{array}{c}10.99 \\
\pm 14.18\end{array}$ & $\begin{array}{l}10.17 \\
\pm 7.32\end{array}$ & $\begin{array}{c}14.82 \\
\pm 10.45\end{array}$ & $\begin{array}{c}9.79 \\
\pm 8.28\end{array}$ & $\begin{array}{r}11.44 \\
\pm 10.42\end{array}$ & NS \\
\hline
\end{tabular}

(*- Significant at $p<0.05$, NS- Not significant)

Table 2. The features of broodstocks developed under three commercial and one laboratory prepared feeds

\begin{tabular}{l|c|c|c|c}
\hline Treatments & $\mathbf{F}_{\mathbf{1}}$ & $\mathbf{F}_{\mathbf{2}}$ & $\mathbf{F}_{\mathbf{3}}$ & $\mathbf{F}_{\mathbf{4}}$ \\
\hline Parameters & & 3 & 3 & 3 \\
\hline $\begin{array}{l}\text { Stocking density of randomly selected male and } \\
\text { female juvenile }\left(\mathrm{no} / \mathrm{m}^{2} \text { ) }\right.\end{array}$ & 3 & & & \\
Total number of stocks & 120 & 120 & 120 & 120 \\
Survival \% (mean \pm SD) & $39.72^{\mathrm{ab}}$ & $37.22^{\mathrm{ab}}$ & $46.11^{\mathrm{a}}$ & $24.72^{\mathrm{b}}$ \\
& \pm 7.23 & \pm 9.29 & \pm 9.71 & \pm 10.69 \\
The first appearance of berried females since PL & 295 & 300 & 300 & 315 \\
stocked (day) & & & & \\
Obtained male and female ratio & $1: 2.8$ & $1: 2.4$ & $1: 2.4$ & $1: 1.7$ \\
\hline
\end{tabular}

Significant at $p<0.05$ 
Table 3. Performance of berried females of producing eggs under broodstocks developed under different feeds

\begin{tabular}{|c|c|c|c|c|}
\hline $\begin{array}{ll}\text { Parameters } & \text { Treatments } \\
\end{array}$ & $\begin{array}{c}\mathbf{F}_{1} \\
(\text { Mean } \pm S D)\end{array}$ & $\begin{array}{c}\mathbf{F}_{\mathbf{2}} \\
(\text { Mean } \pm S D)\end{array}$ & $\begin{array}{c}\mathbf{F}_{3} \\
(\text { Mean } \pm S D)\end{array}$ & $\begin{array}{c}\mathbf{F}_{4} \\
(\text { Mean } \pm S D)\end{array}$ \\
\hline Weight of the berried females $(\mathrm{g})$ & $\begin{array}{l}56.33^{a b} \\
\pm 19.55\end{array}$ & $\begin{array}{l}85.50^{a b} \\
\pm 14.85\end{array}$ & $\begin{array}{l}73.67^{\mathrm{a}} \\
\pm 23.09\end{array}$ & $\begin{array}{l}94.50^{b} \\
\pm 51.62\end{array}$ \\
\hline Total weight of embryonic eggs (g) & $\begin{array}{l}7.61^{b} \\
\pm 1.86\end{array}$ & $\begin{array}{l}7.04^{b} \\
\pm 0.69\end{array}$ & $\begin{array}{l}10.26^{\mathrm{a}} \\
\pm 1.41\end{array}$ & $\begin{array}{l}6.15^{c} \\
\pm 1.20\end{array}$ \\
\hline Axis length of eggs $(\mathrm{mm} \times 0.01)$ & $\begin{array}{l}0.51^{c} \\
\pm 0.02\end{array}$ & $\begin{array}{l}0.62^{\mathrm{a}} \\
\pm 0.06\end{array}$ & $\begin{array}{l}0.60^{b} \\
\pm 0.03\end{array}$ & $\begin{array}{l}0.56^{\mathrm{bc}} \\
\pm 0.03\end{array}$ \\
\hline Transverse length of eggs $\left(\mathrm{mm} \times 0.01^{\star}\right)$ & $\begin{array}{l}0.47^{b} \\
\pm 0.01\end{array}$ & $\begin{array}{l}0.57^{b} \\
\pm 0.05\end{array}$ & $\begin{array}{l}0.51^{\mathrm{a}} \\
\pm 0.03\end{array}$ & $\begin{array}{l}0.48^{\mathrm{c}} \\
\pm 0.04\end{array}$ \\
\hline Numbers of eggs & $\begin{array}{l}53,889^{a} \\
\pm 10,541\end{array}$ & $\begin{array}{c}37,555^{b} \\
\pm 1,217\end{array}$ & $\begin{array}{c}59,640^{a} \\
\pm 5,270\end{array}$ & $\begin{array}{c}36,017^{b} \\
\pm 7,790\end{array}$ \\
\hline
\end{tabular}

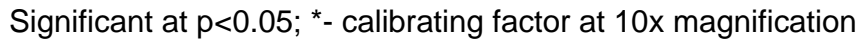

The eggs number depends on the size of the prawn. However, the number of eggs obtained in the present study was between 36,017 and 59,640 among the treatments was more or less similar to the range reported Nandal and Pickering (2005) of 3,000-80,000 (average No. 41,500), 10,000-30,000 (av. No. 20000) stated by New and Singholka (1982) while 5,000-20,000 (av. No. 12,500) mentioned by New (2002). Reproductive performances of broods might vary on the basis of locations (Nhan et al., 2009; Sardar et al., 2013), Yen and Bart (2008) mentioned that brood developed in saline condition showed better performances. However, in the present study, variation of brood performance on producing eggs was observed in the same batch of population when nourished them with different feed regimes in freshwater condition.

In the present experiment, selected feeds were administered to the prawn of the same batch and single environmental condition. It was evident that egg number varies with the proximate composition of feeds. However, suitable commercial feeds might be available to develop broodstocks in the country that could ensure the numbers of berried female potential for production maximum number of eggs. Further experiments could be done to enriched ready feed adding cod liver oil and/or selective vitamins to increase the potentiality of broodstocks that may support the freshwater prawn hatcheries of producing required number post larvae as well to ensure conservation of the natural broodstocks resources.

\section{Conclusion}

Female freshwater prawns fed with commercial feed $F_{3}(C P$ shrimp feed- crude protein, 38.90\%, lipid $8.09 \%$, carbohydrate $25.37 \%$ ) was found to produce the maximum number of eggs $(59,640 /$ female) followed by $F_{1}$ (Mega shrimp feed- crude protein $33.49 \%$, lipid $5.38 \%$, carbohydrate $30.31 \%$ ). The findings may contribute to better management of mass scale broodstock of freshwater prawn, and help to produce of sufficient number embryonic eggs for hatchery operation.

\section{Acknowledgement}

Authors are extending their thanks to BAS USDA authority for their financial support and guidance and to the authority of Bangladesh Agricultural University Research System (BAURES) for administrational cooperation to conduct the research work. 


\section{Reference}

Ahmed, N. 2008. Freshwater prawn hatcheries in Bangladesh: concern of broodstock. Aquaculture Asia Magazine, July- September 2008. 22-26.

Bhatnagar, A. and Devi, P. 2013. Water quality guidelines for the management of pond fish culture. Intl. J. of environmental Sc., 3(6): 1981-2009.

D'Abramo, L.R., Tidwell, J.H., Fondren, M. and Ohs, C.L. 2006. Pond production of the freshwater prawn in temperate climates. Southern Regional Aquaculture Center (SRAC) Publication No. 484.

DoF. 2012. National FisheWeek 2013: Compendium (In Bangla). Department of Fisheries. Ministry of Fisheries and Livestock (MoFL), Bangladesh. 144 p.

DoF. 2013. National FisheWeek 2013: Compendium (In Bangla). Department of Fisheries. Ministry of Fisheries and Livestock (MoFL), Bangladesh. $144 \mathrm{p}$.

Fisher, T.W., Belows, T.S. and Caltagirone, L.E. 1999. The handbook of biological control. T.S. Belows and T.W. Fisher (eds.). Academic press. $139 \mathrm{p}$.

Habashy, M.M., Sharshar K.M. and Hassan M.M.S. 2012. Morphological and histological studies on the embryonic development of the freshwater prawn, Macrobrachium rosenbergii (Crustacea, Decapoda). The Journal of Basic \& Applied Zoology. 65: 157-165.

Mohanta, K.N. 2000. Development of Giant Freshwater Prawn broodstock. Naga, The ICLARM Quarterly. 23(3) 18-20.

Nandlal, S., and Pickering, T. 2005. Freshwater prawn Macrobrachium rosenbergii farming in Pacific Island countries. Volume 1. Hatchery operation. Noumea, New Caledonia: Secretariat of the Pacific Community. 38 pp.

New, M.B. 2002. Farming freshwater prawns, a manual for the culture of the giant river prawn (Macrobrachium rosenbergii. Food and Agriculture Organization of the United Nations. FAO Fisheries Technical Paper 428: 1-10.

New, M.B. and Singholka, S. 1982. Freshwater prawn farming. A manual for the culture of Macrobrachium rosenbergii. FAO Fisheries Technical Paper No. 225.

Nhan, D.T., Wille, M., Hung, L.T. and Sorgeloos, P. 2009. Comparison of reproductive performance and offspring quality of giant freshwater prawn (Macrobrachium rosenbergii) broodstock from different regions. Aquaculture, 298(1-2): 36-42.

Sardar, M.R.I., Mollah, M.F.A. and Khan, M.H.K. 2013. Technique for production of quality brood and seed of galda. In: National FisheWeek 2013: Compendium (In Bangla). Department of Fisheries. Ministry of Fisheries and Livestock (MoFL), Bangladesh. 144 p.

Stirling, H.P. 1985. Chemical and biological methods of water analysis for aquaculturists. Institute of Aquaculture, University of Stirling, Scotland, UK. 119 p.

Tidwell, J.H., D'Abbramo, L.R., Coyle, S.D. and Yasharian, D. 2005. Overview of recent research and development in temperate culture of the freshwater prawn (Macrobrachium rosenbergii De Man) in the South Central United States. Aquaculture Research, Blackwell Publishing Ltd. 36: 264-277.

Yen, P.T. and Bart, A.N. 2008. Salinity effects on reproduction of giant freshwater prawn Macrobrachium rosenbergii (de Man). Aquaculture 280(1-2): 124-128. 